\title{
The efficiency of the use of mineral fertilizers on dry meadows of Prykarpattia
}

\author{
Karbivska Yu. ${ }^{1}$, Kurhak V. ${ }^{2}$ \\ ${ }^{1}$ Vasyl Stefanyk Precarpathian National University \\ 57 Shevchenko Str., Ivano-Frankivsk, Ukraine, 76018 \\ ${ }^{2} \mathrm{NSC}$ «Institute of Agriculture of NAAS» \\ 2b Mashynobudivnykiv Str., Chabany, Kyiv-Sviatoshyn region, Kyiv oblast, Ukraine, 08162 \\ e-mail: ${ }^{1} y l j a k a r b i v s k a @ u k r . n e t,{ }^{2}$ kurgak luki@ukr.net \\ ORCID: ${ }^{10000-0002-0540-8887, ~}{ }^{20000-0003-2309-0128 ~}$
}

Goal. To determine the patterns of formation of productivity of sown cereal grass and feed quality indicators depending on the doses and ratios of mineral fertilizers on sod-podzolic soils of Prykarpattia. Methods. General scientific - hypotheses, inductions and deductions, analogies, generalizations; and special — field, laboratory, mathematical and statistical, computational and comparative. Results. Of the mineral elements, nitrogen had the greatest effect on grass productivity and chemical composition. With the introduction of the total dose of N75 with uniform distribution of nitrogen under each of the 3 slopes on different backgrounds of phosphorus-potassium fertilizers, the productivity of cereal grass increased by $2.82-3.06 \mathrm{t} / \mathrm{ha}$ of dry weight, with the introduction of $\mathrm{N} 150$ - by $3.33-4.93 \mathrm{t} / \mathrm{ha}$, or respectively $1.8-2.1$ and $2.5-2.9$ times. With the introduction of $\mathrm{N}_{75}$, the content of crude protein in the dry mass increased by $2.9-3.2 \%$, with the introduction of $\mathrm{N}_{150}$ - by $4.2-5.4 \%$, or 1.2 and 1.4 times, respectively. The application of nitrogen fertilizers also increased the content of protein, calcium, magnesium, feed units, metabolic energy, dry matter digestibility, the supply of feed unit with digestible protein, and decreased the content of nitrogen-free extractives and potassium. Conclusions. The dependence of the productivity of cereal agrocenosis on sod-podzolic soils of the Carpathian region on doses and ratios of $\mathrm{N}, \mathrm{P}, \mathrm{K}$ of mineral fertilizers is described by a polynomial of the $2 \mathrm{nd}$ degree. The most influential mineral element in terms of increasing productivity and improving feed quality is nitrogen. It provides the highest payback of $1 \mathrm{~kg}$ of fertilizer by increasing the yield of dry mass, which for the application of $\mathrm{N}_{75}$ is $38-41 \mathrm{~kg}$ of dry weight, which is $4-5 \mathrm{~kg}$ more than at the application of $\mathrm{N}_{150}$. Nitrogen fertilizers improve the uniform distribution of the crop on the slopes and increase the content of crude protein. Yield increase from the application of $\mathrm{P}_{60}, \mathrm{~K}_{90}, \mathrm{P}_{30} \mathrm{~K}_{45}$ or $\mathrm{P}_{60} \mathrm{~K}_{90}$ on different nitrogen backgrounds is $0.28-1.34$ $\mathrm{t} /$ ha with a payback of $1 \mathrm{~kg}$ of active substance $5-14 \mathrm{~kg}$ of dry weight.

Key words: nitrogen, cereal grassland, potassium, mathematical model, productivity, crude protein, chemical composition of feed, phosphorus.

DOI: https://doi.org/10.31073/agrovisnyk202008-05

Fertilizers are one of the decisive means of increasing the productivity of meadow grasses on hayfields and pastures, as well as increasing the profitability of land reclamation and other activities. They can be effectively used on all types of meadows. But, first of all, they are highly effective, as noted by P.S. Makarenko [1], VG Kurgak [2], on sufficiently moistened lands (floodplain and lowland meadows, normal land and irrigated areas of meadow pastures), where valuable meadow grasses from the group of cereal mesophytes predominate.

Various methods are used to determine fertilizer doses, including balance-calculation, economicmathematical, chemical diagnostic method, which is based on chemical analysis of plants, and the method, which is based on the recommendations of research institutions [2-4]. The main criterion for determining the doses of fertilizers for hayfields and pastures, when using any method is the experimental data: they are taken as a basis for developing recommendations for fertilizer application. For an approximate determination of nitrogen doses, it is proposed to use the calculated way, based on the average possibility of herbs, to effectively use $2.5 \mathrm{~kg} \mathrm{~N}$ per day.

According to the economic-mathematical method, doses and ratios of basic nutrients are optimized with the help of special mathematical models of productivity, which in a concise form contain information for certain soil and climatic conditions and types of onions, on the quantitative relationship between doses and ratios of nutrients and yields of meadows. . In addition, they provide an opportunity to solve a number of other tasks: to plan (predict) yields and agro-technological (economic and energy) efficiency of fertilizers, machines and methods of their application [5], to develop standards for onions and pastures in mineral fertilizers, etc. [2].

Research conducted by L.M. Derzhavin and IA Rubanov [6], proved that the best functions of "harvestfertilizer" are functions degree 0.5 and square. For practical use, successful, in our opinion, is a classical model using a quadratic mathematical function (polynomial of the second degree), which with sufficient accuracy allows not only to determine doses, predict yields depending on them, but also on the basis of predicted yield to assess the quality of mineral application fertilizers [5, 7].

Despite the significant amount of research on the study of fertilizer doses, until recently experimental data using modern methods of planning and modeling experiments with fertilizers on natural forage lands in the Carpathians of Ukraine are still insufficient. Therefore, these questions were the purpose of our research. 
The purpose of the work. To establish regularities of formation of productivity of sown cereal grass and forage quality indicators depending on doses and ratios of mineral fertilizers on sod-podzolic soils of Prykarpattia.

Materials and methods of research. A study to determine the productivity of cereal grass and chemical composition of feed from doses and ratios of nitrogen, phosphorus and potassium we conducted in a threefactor field experiment on poor in humus and nutrient content sod-podzolic surface gleyed soil during 2017 2019 in the dendrology "Druzhba" SHEl "Precarpathian National University" (Tysmenets district of IvanoFrankivsk region). Coverless sowing of a mixture of cereal grasses from meadow thyme, thistle and meadow fire was carried out in the summer of 2016.

The use of stands is triangular. The first mowing was carried out in the phase of earing cereals buddingbeginning of flowering legumes, otav - 30-35 days after the previous mowing.

Phenological observations and crop accounting in each slope on the accounting plots were performed according to SSTU 8044: 2015 [8]; productivity indicators on the yield of 1 ha of dry mass, feed units, crude protein and metabolic energy - according to SSTU 8044: 2015 [8] and SSTU 8066: 2015 [9]. In the dry mass of plant mass indicators of chemical composition of feed and in vitro digestibility - by infrared spectroscopy, nutritional value and energy of feed - by calculation according to SSTU 8066: 2015 [9] and SSTU 4674: 2006 [10].

The experiment was carried out according to an abbreviated scheme, which is recommended when planning experiments [2,3] Mathematical processing of research results was performed by methods of variance and regression analysis according to Dospekhov BA [12].

Research results. Analysis of the results of our studies conducted during 2017-2019 to study the doses and ratios of NPK mineral fertilizers showed that on sown cereal grass in the first year of use, the proportion of meadow thyme was $7-9 \%$, foxglove $20-23 \%$ and meadow fireweed. $55-58 \%$. Over the years, and to the greatest extent against the background of the introduction of $\mathrm{N}_{150}$, the share of stokolos bezzostogo increased, and meadow bonfire decreased by $31-40 \%$.

Nitrogen was the most effective mineral nutrient in terms of its effect on productivity (Table 1). For example, the application of its total dose of $\mathrm{N}_{75}(25+25+25)$ on different backgrounds of phosphorus-potassium fertilizers, the productivity of cereal grasses for an average of three years increased from 2.53-3.47 t/ha to 5.35-6, 53 t/ha of dry mass or 2.82-3.06 t/ha or 1.8-2.1 times, and for the application of $\mathrm{N}_{150(50+50+50)}-$ up to $7.46-8.80$ tons/ha or 4.93-3.33 t/ha or 2.5-2.9 times. Thus, the highest productivity of grass feed was obtained when $\mathrm{N}_{150}$ was applied. However, the payback of $1 \mathrm{~kg}$ of nitrogen fertilizers with dry matter yield was higher than the application of $N_{75}$, which ranged from 38 to $41 \mathrm{~kg}$, which is $3-5 \mathrm{~kg}$ more than the application of nitrogen at a dose of $\mathrm{N}_{150}$.

Phosphorus and potassium fertilizers had much less effect on the productivity of sown cereals. The increase in yield from the use of phosphorus at a dose of P60 on different nitrogen backgrounds ranged from 0.28 to $0.56 \mathrm{t} / \mathrm{ha}$ with a payback of $1 \mathrm{~kg}$ of active substance $5-9 \mathrm{~kg}$ of dry weight. The increase in yield from the introduction of potassium at a dose of $\mathrm{K} 90$ on different nitrogen backgrounds was equal to $0.42-0.74 \mathrm{t} / \mathrm{ha}$ with a payback of $1 \mathrm{~kg}$ of active substance $5-8 \mathrm{~kg}$ of dry weight. With the combined application of phosphorus and potassium in doses of $\mathrm{P}_{60} \mathrm{~K}_{90}$ and $\mathrm{P}_{30} \mathrm{~K}_{45}$ on different nitrogen backgrounds, the productivity of sown grass increased by $0.60-1.34 \mathrm{t} / \mathrm{ha}$ of dry mass with a payback of $1 \mathrm{~kg}$ of their active substance from $6 \mathrm{to} 14 \mathrm{~kg}$. Higher payback rates were for the introduction of $\mathrm{P}_{30} \mathrm{~K}_{45}$. Slightly larger increases in dry matter yield from the application of phosphorus and potassium fertilizers and the payback of $1 \mathrm{~kg}$ of these fertilizers by dry weight were against the background of nitrogen fertilizers.

The intermediate position of payback between the use of only nitrogen fertilizers or only phosphorus and potassium fertilizers was occupied by the joint application of nitrogen with phosphorus and potassium fertilizers. In this case, the payback of $1 \mathrm{~kg}$ of active substance fertilizer ranged from 18 to $27 \mathrm{~kg}$. The greatest productivity was at the combined introduction in the maximum investigated doses $\mathrm{N}_{150} \mathrm{P}_{60} \mathrm{~K}_{90}$. In this case, the yield from 1 ha of dry matter was $8.80 \mathrm{t} / \mathrm{ha}$, which is 3.5 times more than the option without fertilizer.

1. The effect of doses and ratios of NPK fertilizers on the productivity of cereal grass (2017-2019 yy.)

\begin{tabular}{|c|c|c|c|c|c|c|c|}
\hline \multirow{3}{*}{ oses of fertilizers } & \multirow{2}{*}{\multicolumn{3}{|c|}{ Dry weight by years, t/ha }} & \multicolumn{4}{|c|}{ Average for 2017-2019 yу. } \\
\hline & & & & \multirow{2}{*}{$\begin{array}{c}\text { dry weight, } \\
\text { t/ha }\end{array}$} & \multirow{2}{*}{$\begin{array}{l}\text { of crude } \\
\text { protein, } \\
\text { t/ha }\end{array}$} & \multirow{2}{*}{$\begin{array}{l}\text { of feed } \\
\text { units, } \\
\text { t/ha }\end{array}$} & \multirow{2}{*}{$\begin{array}{c}\text { of metabolic } \\
\text { energy, } \\
\text { GJ/ha }\end{array}$} \\
\hline & 2017 & 2018 & 2019 & & & & \\
\hline Without kind & 2,71 & 2,57 & 2,30 & 2,53 & 0,27 & 1,82 & 20,4 \\
\hline $\mathrm{P}_{60}$ & 2,96 & 2,77 & 2,70 & 2,81 & 0,33 & 2,05 & 22,5 \\
\hline $\mathrm{K}_{90}$ & 3,14 & 2,90 & 2,82 & 2,95 & 0,33 & 2,12 & 23,6 \\
\hline $\mathrm{P}_{30} \mathrm{~K}_{45}$ & 3,35 & 3,09 & 2,94 & 3,13 & 0,35 & 2,22 & 25,4 \\
\hline $\mathrm{P}_{60} \mathrm{~K}_{90}$ & 3,78 & 3,38 & 3,24 & 3,47 & 0,40 & 2,46 & 28,1 \\
\hline $\mathrm{N}_{75}$ & 5,57 & 5,34 & 5,13 & 5,35 & 0,70 & 3,91 & 43.3 \\
\hline $\mathrm{N}_{75} \mathrm{P}_{60}$ & 6,19 & 5,61 & 5,49 & 5,76 & 0,78 & 4,20 & 46,7 \\
\hline $\mathrm{N}_{75} \mathrm{~K}_{90}$ & 6,31 & 5,59 & 5,53 & 5,81 & 0,80 & 4,24 & 47,1 \\
\hline $\mathrm{N}_{75} \mathrm{P}_{30} \mathrm{~K}_{45}$ & 6,48 & 6,03 & 5,89 & 6,13 & 0,81 & 4,54 & 50,3 \\
\hline $\mathrm{N}_{75} \mathrm{P}_{60} \mathrm{~K}_{90}$ & 6,78 & 6,55 & 6,25 & 6,53 & 0,90 & 4,83 & 53,5 \\
\hline
\end{tabular}




\begin{tabular}{|l|l|l|l|l|l|l|l|}
\hline $\mathrm{N}_{150}$ & 8,13 & 7,19 & 7,06 & 7,46 & 1,09 & 5,52 & 61,2 \\
\hline $\mathrm{N}_{150} \mathrm{P}_{60}$ & 8,66 & 7,81 & 7,59 & 8,02 & 1,21 & 5,93 & 65,8 \\
\hline $\mathrm{N}_{150} \mathrm{~K}_{90}$ & 8,75 & 8,09 & 7,76 & 8,20 & 1,25 & 6,07 & 67,2 \\
\hline $\mathrm{N}_{150} \mathrm{P}_{30} \mathrm{~K}_{45}$ & 9,08 & 8,34 & 8,07 & 8,50 & 1,36 & 6,38 & 70,6 \\
\hline $\mathrm{N}_{150} \mathrm{P}_{60} \mathrm{~K}_{90}$ & 9,28 & 8,75 & 8,38 & 8,80 & 1,41 & 6,60 & 73,0 \\
\hline $\mathrm{SSD}_{05}, \mathrm{t} / \mathrm{ha}$ & 0,44 & 0,38 & 0,33 & 0,38 & & & \\
\hline
\end{tabular}

The dependence of productivity $(\mathrm{Y})$ in $\mathrm{t} /$ ha of grassland on doses and ratios $\mathrm{N}, \mathrm{P}, \mathrm{K}$ is described by the equation of the second degree:

$Y=2.53+4.22 \mathrm{~N}-0.58 \mathrm{~N}^{2}-0.08 \mathrm{P}+1.04 \mathrm{P}^{2}+2.13 \mathrm{~K}-1.84 \mathrm{~K}^{2}+0.2 \mathrm{NP}+0.16 \mathrm{NK}+0.36 \mathrm{PK}$, where $\mathrm{N}$, $P, K$, respectively, the dose of nitrogen, phosphorus and potassium, $c / h a$.

The mathematical model is valid by the criterion of Fisher $(\mathrm{F})$ and Student at $95 \%$ probability. $\mathrm{F}$ is actually equal to 1488 when $\mathrm{F}$ is tabular 6 . The multiple correlation coefficient is equal to 0.997 .

Graphically, this model is shown in Figure 1. This model allows not only to predict the productivity and agrotechnological efficiency of mineral fertilizers on sown cereals, but also to determine the doses of mineral fertilizers on poor sod-podzolic soils of the Carpathian region.

Productivity also changed significantly over the years of use of sown cereals. It was the largest in 2017 the 1 st year of grassland use and the 2 nd year of grass life. The yield from 1 ha of dry mass this year on different fertilizer options ranged from 2.71 to 9.28 tons, which is 1.1 times more than in 2019 , where it ranged from 2.30 to $8.38 \mathrm{t} / \mathrm{ha}$. Regularities regarding the effect of doses and ratios, which were on average three years of research were maintained in each year of use of the herbage.

The obtained regularity of productivity of sown cereal grass depending on doses and ratios of NPK on an exit from 1 hectare of dry weight was the same and on an exit from 1 hectare of dry weight, crude protein, forage units and exchange energy. On the same phosphorus-potassium backgrounds, the highest performance according to these indicators was when applying $N_{150}$. The yield of 1 ha of crude protein in this case for different applications of phosphorus and potassium fertilizers on average over three years of research increased from $0.27-0.40$ to $1.09-1.41 \mathrm{t} / \mathrm{ha}$ or 3.5-4.0 times, fodder units - from 1.82-2.46 to $5.52-6.60 \mathrm{t} / \mathrm{ha}$ or 2.7-3.0 times, metabolic energy - from 20.4-28.1 up to 61.2-73.0 GJ/ha or 2.6-3.0 times. With the introduction of $\mathrm{N}_{75}$ yield of 1 ha of crude protein for different applications of phosphorus and potassium fertilizers increased by 2.3-2.6 times, feed units - 1.9-2.1 times, metabolic energy - 1.9 times.

The highest productivity in terms of yield of 1 ha of nutrients as well as in terms of dry mass yield was when applying the maximum investigated doses of fertilizers, namely $\mathrm{N}_{150} \mathrm{P}_{60} \mathrm{~K}_{90}$, when it increased by 3.6-5.2 times compared to the option without fertilizer application.

According to our data, the application of nitrogen fertilizers significantly improved the uniformity of crop distribution on the slopes. The most uniform distribution of the crop on the slopes was obtained in the variants with the introduction of nitrogen at a dose of $\mathrm{N}_{150}$. In this case, the uneven distribution of the crop on the slopes, expressed by the coefficient of variation, was $5-7 \%$ with a share of the 1 st slope of $35 \%$, the 2 nd $-33-34$, the $3 \mathrm{rd}-31-32 \%$. When applying $\mathrm{N}_{75}$, it was at the level of $10-13 \%$ with the share of these slopes, respectively, $36-37 \%, 33-34$ and $31-32 \%$. With the introduction of phosphorus and potassium without nitrogen, it was $30-$ $31 \%$ with the share of these slopes in the total yield of $40-41 \%, 38-39 \%$ and $21-22 \%$.

The analysis of absolute indicators of productivity showed that the regularity which was received in the sum for all slopes remained and in each slope. For the introduction of the same doses of phosphorus and potassium, it was the largest for the application of $N_{50}$ under the slope, and the smallest - without the introduction of nitrogen. The application of nitrogen fertilizers had a positive effect on the regrowth of grasses and the formation of productivity in otava. However, regardless of the fertilizer options, the highest productivity was obtained in the 1st slope and the lowest - in the 3rd.

Analysis of the chemical composition of the feed of cereal grasses depending on the doses and ratios of the main nutrients showed that the most effective element that most significantly affected the quality of feed was nitrogen (Table 2). With the introduction of $\mathrm{N}_{75}$, the share of crude protein in the dry weight of feed compared to without nitrogen backgrounds increased by $1.9-2.7 \%$, and with $\mathrm{N}_{150}-$ by $3.8-4.5 \%$. At the same time, the protein content increased by $1.8-1.9 \%$ and $3.4-3.6 \%$ and decreased the content of nitrogen-free extractives by $1.7-2.1$ and $3.5-3.9 \%$, respectively.

When nitrogen was applied, the digestibility of the dry mass of feed slightly increased compared to the variants without its application, but as well as the content of crude protein and crude fiber was within the zootechnical norm.

2. The content of organic matter in the feed and digestibility of sown cereal grass depending on the doses of fertilizers, \% in dry weight (average for 2017-2019 yy.)

\begin{tabular}{|l|c|c|c|c|c|c|}
\hline \multicolumn{1}{|c|}{ Fertilizers } & $\begin{array}{c}\text { Crude } \\
\text { Protein }\end{array}$ & Protein & $\begin{array}{c}\text { Crude } \\
\text { Fat }\end{array}$ & $\begin{array}{c}\text { Crude } \\
\text { cellulose }\end{array}$ & NFE & $\begin{array}{c}\text { Re- } \\
\text { digestion }\end{array}$ \\
\hline Without fertilizers & 10,8 & 9,0 & 3,3 & 29,7 & 47,0 & 54 \\
\hline $\mathrm{P}_{60}$ & 11,6 & 9,6 & 3,4 & 29,5 & 46,1 & 55 \\
\hline
\end{tabular}




\begin{tabular}{|c|c|c|c|c|c|c|}
\hline $\mathrm{K}_{90}$ & 11,1 & 9,2 & 3,4 & 30,6 & 45,5 & 56 \\
\hline $\mathrm{P}_{30} \mathrm{~K}_{45}$ & 11,3 & 9,6 & 3,5 & 29,9 & 46,0 & 55 \\
\hline $\mathrm{P}_{60} \mathrm{~K}_{90}$ & 11,5 & 9,7 & 3,5 & 29,8 & 45,8 & 56 \\
\hline $\mathrm{N}_{75}$ & 13,0 & 10,8 & 3,4 & 29,3 & 44,9 & 55 \\
\hline $\mathrm{N}_{75} \mathrm{P}_{60}$ & 13,5 & 11,1 & 3,5 & 29,1 & 44,2 & 56 \\
\hline $\mathrm{N}_{75} \mathrm{~K}_{90}$ & 13,8 & 11,3 & 3,5 & 29,3 & 43,8 & 56 \\
\hline $\mathrm{N}_{75} \mathrm{P}_{30} \mathrm{~K}_{45}$ & 13,2 & 11,4 & 3,5 & 29,2 & 44.6 & 56 \\
\hline $\mathrm{N}_{75} \mathrm{P}_{60} \mathrm{~K}_{90}$ & 13,8 & 11,6 & 3,6 & 29,1 & 43,8 & 57 \\
\hline$N_{150}$ & 14,6 & 12,4 & 3,6 & 28,5 & 43,5 & 56 \\
\hline $\mathrm{N}_{150} \mathrm{P}_{60}$ & 15,1 & 12,5 & 3,6 & 28,2 & 43,2 & 57 \\
\hline $\mathrm{N}_{150} \mathrm{~K}_{90}$ & 15,3 & 12,7 & 3,7 & 28,5 & 42,7 & 57 \\
\hline $\mathrm{N}_{150} \mathrm{P}_{30} \mathrm{~K}_{45}$ & 16,0 & 13,2 & 3,7 & 28,4 & 41,8 & 58 \\
\hline $\mathrm{N}_{150} \mathrm{P}_{60} \mathrm{~K}_{90}$ & 16,0 & 13,3 & 3,7 & 28,5 & 41,6 & 58 \\
\hline $\mathrm{SSD}_{05}$ & 0,7 & 0,6 & 0,2 & 1,2 & & 2 \\
\hline Zootechnical norm & 14 & & & $25-30$ & & $50-70$ \\
\hline
\end{tabular}

Under the influence of nitrogen fertilizers, the nutritional value of feed in terms of feed units and energy consumption in terms of metabolic energy and, to a greater extent, the supply of feed feed in digestible protein also changed (Table 3). With the introduction of $\mathrm{N}_{150}$ compared to the options without nitrogen, the content of feed units in the dry mass increased from $72-73 \%$ to $74-75 \%$ at a zootechnical rate of $80-90 \%$, and the content of metabolic energy - from $8.0-8.1$ to $8.2-8.3 \mathrm{MJ} / \mathrm{kg}$ at a rate of $8-9 \mathrm{MJ} / \mathrm{kg}$.

3. Nutrition and energy saturation of dry mass of forage of cereal grasses depending on doses of fertilizers (average for 2017-2019 yy.)

\begin{tabular}{|c|c|c|c|}
\hline Fertilizers & $\begin{array}{l}\text { Content of feed } \\
\text { units, } \%\end{array}$ & $\begin{array}{l}\text { Content of exchange } \\
\text { energy, } \mathrm{MJ} / \mathrm{kg}\end{array}$ & $\begin{array}{l}\text { Provision of feed. from } \\
\text { digestible protein, } g\end{array}$ \\
\hline Without fertilizers & 72 & 8,1 & 104 \\
\hline $\mathrm{P}_{60}$ & 73 & 8,0 & 112 \\
\hline$K_{90}$ & 72 & 8,0 & 108 \\
\hline $\mathrm{P}_{30} \mathrm{~K}_{45}$ & 72 & 8,1 & 108 \\
\hline $\mathrm{P}_{60} \mathrm{~K}_{90}$ & 73 & 8,1 & 113 \\
\hline $\mathrm{N}_{75}$ & 73 & 8,1 & 125 \\
\hline $\mathrm{N}_{75} \mathrm{P}_{60}$ & 73 & 8,1 & 131 \\
\hline $\mathrm{N}_{75} \mathrm{~K}_{90}$ & 73 & 8,1 & 132 \\
\hline $\mathrm{N}_{75} \mathrm{P}_{30} \mathrm{~K}_{45}$ & 74 & 8,2 & 126 \\
\hline $\mathrm{N}_{75} \mathrm{P}_{60} \mathrm{~K}_{90}$ & 74 & 8,2 & 130 \\
\hline $\mathrm{N}_{150}$ & 74 & 8,2 & 137 \\
\hline $\mathrm{N}_{150} \mathrm{P}_{60}$ & 74 & 8,2 & 143 \\
\hline $\mathrm{N}_{150} \mathrm{~K}_{90}$ & 74 & 8,2 & 144 \\
\hline $\mathrm{N}_{150} \mathrm{P}_{30} \mathrm{~K}_{45}$ & 75 & 8,3 & 148 \\
\hline $\mathrm{N}_{150} \mathrm{P}_{60} \mathrm{~K}_{90}$ & 75 & 8,3 & 150 \\
\hline Zootechnical norm & $80-90$ & $8,0-9,0$ & $110-120$ \\
\hline
\end{tabular}

With the introduction of $\mathrm{N}_{75}$ compared to the options without nitrogen, the supply of feed unit digestible protein increased from $104-113$ to $125-132 \mathrm{~g}$ or $19-21 \%$, and with the introduction of $\mathrm{N}_{150}-$ up to $137-150 \mathrm{~g}$ or $33-37 \%$ at the zootechnical norm $110-120$.

According to our data, under the influence of mineral fertilizers, the mineral composition of fodder sown with cereal grass changed significantly (Table 4). In particular, under the influence of nitrogen fertilizers, the content of crude ash, calcium, magnesium slightly increased and the content of potassium decreased, the ratio of calcium to phosphorus increased and the ratio of potassium to the sum of calcium and magnesium decreased. With the introduction of $\mathrm{N}_{150}$ compared to the options without nitrogen, the ash content tended to increase by $0.6-0.8 \%$.

With the introduction of $\mathrm{N}_{75}$ compared to the options without nitrogen, the calcium content increased by $0.03-0.4 \%$, and $\mathrm{N}_{150}$ - by $0.11-0.12 \%$, magnesium, respectively - by $0.01-0.02$ and $0.02-0.03$, and potassium decreased by $0.15-0.20$ and $0.32-0.32 \%$, respectively. 
4. Mineral composition of cereal grass feed depending on the doses of fertilizers, $\%$ in dry weight (average for 2017-2019 yy.)

\begin{tabular}{|c|c|c|c|c|c|c|c|}
\hline Fertilizers & Crude ash & $P$ & $K$ & $\mathrm{Ca}$ & $\mathrm{Mg}$ & $\mathrm{K}:(\mathrm{Ca}+\mathrm{Mg})$ & Ca:P \\
\hline Without fertilizers & 9,2 & 0,33 & 2,40 & 0,41 & 0,10 & 4,7 & 1,2 \\
\hline $\mathrm{P}_{60}$ & 9,4 & 0,36 & 2,43 & 0,40 & 0,11 & 4,8 & 1,1 \\
\hline $\mathrm{K}_{90}$ & 9,4 & 0,35 & 2,65 & 0,41 & 0,12 & 5,0 & 1,2 \\
\hline $\mathrm{P}_{30} \mathrm{~K}_{45}$ & 9,3 & 0,36 & 2,55 & 0,42 & 0,11 & 4,8 & 1,2 \\
\hline $\mathrm{P}_{60} \mathrm{~K}_{90}$ & 9,4 & 0,36 & 2,61 & 0,43 & 0,11 & 4,8 & 1,2 \\
\hline $\mathrm{N}_{75}$ & 9,4 & 0,32 & 2,25 & 0,46 & 0,12 & 3,9 & 1,4 \\
\hline $\mathrm{N}_{75} \mathrm{P}_{60}$ & 9,7 & 0,35 & 2,20 & 0,46 & 0,12 & 3,8 & 1,3 \\
\hline $\mathrm{N}_{75} \mathrm{~K}_{90}$ & 9,6 & 0,33 & 2,41 & 0,45 & 0,13 & 4,2 & 1,4 \\
\hline $\mathrm{N}_{75} \mathrm{P}_{30} \mathrm{~K}_{45}$ & 9,5 & 0,34 & 2,28 & 0,46 & 0,12 & 3,9 & 1,4 \\
\hline $\mathrm{N}_{75} \mathrm{P}_{60} \mathrm{~K}_{90}$ & 9,7 & 0,35 & 2,37 & 0,47 & 0,12 & 4,0 & 1,3 \\
\hline $\mathrm{N}_{150}$ & 9,8 & 0,31 & 2,08 & 0,52 & 0,13 & 3,2 & 1,7 \\
\hline $\mathrm{N}_{150} \mathrm{P}_{60}$ & 9,9 & 0,34 & 2,11 & 0,55 & 0,13 & 3,1 & 1,6 \\
\hline $\mathrm{N}_{150} \mathrm{~K}_{90}$ & 9,9 & 0,32 & 2,28 & 0,55 & 0,14 & 3,2 & 1,7 \\
\hline $\mathrm{N}_{150} \mathrm{P}_{30} \mathrm{~K}_{45}$ & 10,1 & 0,33 & 2,21 & 0,56 & 0,13 & 3,2 & 1,7 \\
\hline $\mathrm{N}_{150} \mathrm{P}_{60} \mathrm{~K}_{90}$ & 10,2 & 0,35 & 2,27 & 0,54 & 0,14 & 3,3 & 1,5 \\
\hline $\mathrm{SSD}_{05}$ & 0,5 & 0,02 & 0,17 & 0,03 & 0,01 & & \\
\hline Zootechnical norm & & $\begin{array}{l}0,2- \\
0,35\end{array}$ & $1-3$ & $0,3-0,6$ & $\begin{array}{c}0,12- \\
0,26 \\
\end{array}$ & & $0,7-2,5$ \\
\hline
\end{tabular}

The ratio of calcium to phosphorus with the introduction of $\mathrm{N}_{75}$ increased from 1.1-1.2 to 1.3-1.4, and $\mathrm{N}_{150}-$ up to 1.5-1.7, and the ratio of potassium to the sum of calcium and magnesium, respectively, decreased from 4, 7-5.0 to 3.8-4.2 and up to 3.1-3.3.

Significantly increased the potassium content in the grass under the influence of potassium fertilizers. For example, when applying $K_{90}$ compared to options without fertilizer or with the application of $N_{75}$ or $N_{150}$, the potassium content in the dry weight of the feed increased by $0.16-0.25 \%$. There was a tendency to increase the content of grass and phosphorus by $0.03 \%$ under the action of phosphorus fertilizers.

When comparing the mineral composition of forage with grass, as well as the ratio of calcium to phosphorus and the ratio of potassium to the amount of calcium and magnesium with zootechnical standards, it was found that it mainly met zootechnical standards for feeding cattle.

When comparing the chemical composition in the dry mass of feed from cereals perennial grasses, mowed in the earing phase, the content of crude protein and crude fiber, as well as nutrients in terms of feed units and energy content in terms of metabolic energy from SSTU to grass feed (hay, haylage, artificially dried grass forages, green forages) [13-16] it was found that the grass mainly meets their requirements. With the introduction of $\mathrm{N}_{75}$ or $\mathrm{N}_{150}$ green mass is suitable for the production of hay and haylage of the 1st class. On various variants of application only of phosphorus and potassium fertilizers, and also without fertilizers it is suitable, mainly, for production of hay and haylage of the 2-nd or 3-rd classes. With the introduction of $\mathrm{N}_{150}$, the green mass is also suitable for the production of grass meal, mainly of the 3-rd class.

\section{Conclusions}

The dependence of the productivity of cereal agrocenosis on sod-podzolic soils of the Carpathian region on the doses and ratios $N, P, K$ of mineral fertilizers is described by a polynomial of the 2nd degree. Among the mineral elements, nitrogen is the most effective on the productivity of sown grass and forage quality indicators. With the introduction of the total dose of $N_{75}$ with a uniform distribution of nitrogen under each of the three slopes on different backgrounds with the introduction of phosphorus and potassium fertilizers, the productivity of cereal grass increases by 2.82-3.06 t/ha, and with the introduction of $N_{150}-$ by 3.33-4, 93 t/ha with a payback of $1 \mathrm{~kg}$ of active substance $33-41 \mathrm{~kg}$.

The increase in yield from the introduction of $P_{60}, K_{90}, P_{30} K_{45}$, or $P_{60} K_{90}$ on different nitrogen backgrounds ranged from 0.28 to 1.34 t/ha with a payback of $1 \mathrm{~kg}$ of active substance $5-9 \mathrm{~kg}$ of dry weight.

With the introduction of $\mathrm{N}_{75}$ the content of crude protein in the dry weight increases from 10.8-11.5 to 13.0$13.8 \%$ or $2.9-3.2 \%$, and with $N_{150}-$ up to $14.6-16.0$ or $4.2-5.4 \%$. The application of nitrogen fertilizers also increases the content of protein, calcium, magnesium, dry weight digestibility, feed feed content, metabolic energy content, feed feed supply of digestible protein and decreases the content of nitrogen-free extractives and potassium and the ratio of potassium to calcium. The potassium content in the grass increases with the application of potassium fertilizers. 


\section{References}

1. Makarenko, P. S. (1990). Vliyanie udobreniy na produktivnost seyanykh poymennykh lugov, kachestvo korma i plodorodie pochvy [The influence of fertilizers on the productivity of sown floodplain meadows, the quality of forage and soil fertility]. Agrochemistry, 10, 51-58. [In Russian].

2. Kurhak, V. H. (2010). Luchni ahrofitotsenozy [Meadow agrophytocenoses]. Kyiv: DIA. [In Ukrainian].

3. Kayumov, M. K. (1976). Opyt polucheniya zaplanirovannykh urozhaev. Programmirovanie urozhaev s.-kh. kultur [Experience in obtaining planned harvests. Programming of agricultural yields cultures]. Chisinau: Shtiintsa. (pp. 48-56). [In Russian].

4. Peregudov, V. N., \& Ivanova, T. I. (1976). Prognozirovanie effektivnosti udobreniy na osnove matematicheskikh modeley s ispolzovaniem EVM [Predicting the effectiveness of fertilizers based on mathematical models using computers]. Chemistry in agriculture, 14, 6, 69-75. [In Russian].

5. Makovetskiy, O. A., Kurgak, V. G., \& Osmak, G. M. (1982). Vybor sposobov i optimalnykh rezhimov raboty mashin pri vnesenii mineralnykh udobreniy. Ekspress-informatsiya: metody i organizatsiya ispytaniy selskokhozyaystvennoy tekhniki [The choice of methods and optimal operating modes of machines when applying mineral fertilizers. Express information: methods and organization of agricultural machinery testing]. Moscow. (Vol. 10, pp. 1-8). [In Russian].

6. Derzhavin, L. M., \& Rubanov, I. A. (1975). Vid i analiz proizvodstvennoy funktsii «urozhay udobrenie» [Type and analysis of the production function "crop - fertilizer"]. Agrochemistry, 4, 125130. [In Russian].

7. Kurhak, V. H., \& Havryk, S. S. (2012). Optymizatsiia doz mineralnykh dobryv ta rezhymiv vykorystannia siianoho zlakovoho travostoiu [Optimization of mineral fertilizer doses and modes of use sown cereal grass]. Kormy i kormovyrobnytstvo: mizhvid. temat. nauk. zb. [Feed and feed production]. Vinnytsia. (Vol. 72, pp. 176-182). [In Ukrainian].

8. DSTU 8044:2015. Uhiddia pryrodni kormovi. Metody vyznachennia produktyvnosti. (2018). [DSTU 8044: 2015. Natural forage lands. Methods for determining productivity]. Kyiv. [In Ukrainian].

9. DSTU 8066:2015. Kormy dlia silskohospodarskykh tvaryn. Metody vyznachennia enerhoiemnosti i pozhyvnosti. (2017). [Feed for farm animals. Methods for determining energy consumption and nutritional value]. Kyiv. [In Ukrainian].

10. DSTU 4674:2006. Sino. Tekhnichni umovy. (2008). [Hay. Specifications]. Kyiv. [In Ukrainian].

11. Dospekhov, B. A. (1985). Metodika polevogo opyta (s osnovami statisticheskoy obrabotki rezultatov issledovaniy) [Methods of field experience (with the basics of statistical processing of research results)]. Moscow: Kolos. [In Russian].

12. Popov, V. V. (1973). Zootekhnicheskie trebovaniya k kachestvu rastitelnykh kormov. Doklad i soobshch. po kormoproizvodstvu: tr. VPK [Zootechnical requirements for the quality of plant feed. Report and communication for feed production]. Moscow. (Vol. 5, pp. 254-263). [In Russian].

13. DSTU 4674:2006. Sino. Tekhnichni umovy. (2008). [Hay. Specifications]. Kyiv. [In Ukrainian].

14. DSTU 4684:2006. Sinazh. Tekhnichni umovy. (2008). [Soilage. Specifications]. Kyiv [In Ukrainian].

15. DSTU 4685:2006. Kormy traviani shtuchno vysusheni. Tekhnichni umovy. (2008). [Herbal fodder is artificially dried. Specifications]. Kyiv [In Ukrainian].

16. DSTU 8528:2015. Kormy zeleni. Tekhnichni umovy. (2017). [Green fodder. Specifications]. Kyiv [In Ukrainian]. 